\title{
MODULATORY ACTIVITY OF ANTIOXIDANTS AGAINST THE TOXICITY OF RIFAMPICIN in vivo
}

\author{
Olufunsho AWODELE(1), Alade AKINTONWA(1), Vincent O. OSUNKALU(2) \& Herbert A.B. COKER(3)
}

\begin{abstract}
SUMMARY
The World Health Organization (WHO) has shown concern about the burden of tuberculosis in the developing countries. Even though rifampicin is an effective drug in the management of tuberculosis, it has been documented to have some toxic effects in humans. Therefore, this study intends to investigate the modulatory effect of vitamins $\mathrm{C}$ and $\mathrm{E}$ on the hepatotoxicity, sperm quality and brain toxicity of Rifampicin.

Forty Wistar albino rats were used, 10 animals per group. Group 1 animals received $0.3 \mathrm{~mL}$ of distilled water, the Group 2 animals received the therapeutic dose of rifampicin, Group 3 animals received therapeutic doses of rifampicin plus vitamin E, while Group 4 received therapeutic doses of rifampicin and vitamin $\mathrm{C}$. The administration was performed orally during three months; the animals were sacrificed by cervical dislocation at the end of that period. Blood samples were collected and liver function and lipid profile was analyzed using fully automated clinical chemistry device. The liver, brain and reproductive organs underwent histopathological examination. Sperm samples were collected from the epididymis to achieve count and motility and morphological analysis.

Results showed rifampicin alone to raise $(\mathrm{p}<0.05)$ liver function enzymes (Aspartate amino transferase [AST], Serum alanine amino transferase [ALT] and Total Bilirubin) when compared with controls. While the vitamin E treated group showed remarkable protection, the vitamin $\mathrm{C}$ treated group showed questionable protection against the rifampicin induced liver damage. Sperm count results showed an important $(\mathrm{p}<0.05)$ increase in the sperm quality in vitamin $\mathrm{E}$ and $\mathrm{C}$ treated groups. However, the vitamin $\mathrm{E}$ plus Rifampicin treated group showed increased lipid peroxidation. The histopathological findings revealed structural damages by rifampicin in liver, brain and epididymis while some remarkable architectural integrity was observed in the antioxidant-treated groups.

It can be concluded that vitamin $\mathrm{E}$ or $\mathrm{C}$ improved sperm quality and protected against the brain damage caused by rifampicin. Moreover, vitamin $\mathrm{E}$ demonstrated remarkable hepatoprotection against rifampicin induced damage while vitamin $\mathrm{C}$ shows a questionable hepatoprotection.
\end{abstract}

KEYWORDS: Rifampicin; Antioxidants; Modulation; Toxicity; Vitamin C; Vitamin E; Liver; Brain and sperm quality.

\section{INTRODUCTION}

Reduction of disease burden is one of the main targets of the millennium development goals. Tuberculosis has been known to represent a great burden in the developing countries. Thus, rifampicin is a widely used antimicrobial agent, which is a crucial component in treatment regimens for tuberculosis and has been in use since the early 1970's (REKHA et al., 2005). It has also been employed in the treatment of non-tuberculosis infections, especially serious Staphylococcal infections (KATZ \& LOR, 1986). The World Health Organization (WHO) has recently revised the treatment guidelines for National Tuberculosis Programmes and encouraged the use of fixed dose combination drugs (WHO, 1997).

Despite the inevitable use of rifampicin in the management of tuberculosis, it has been reported by many researchers to have several toxicological effects. The works of SARASWAT et al., 1997, KATZ \& LOR, 1986, REKHA et al., 2005, GABOW et al., 1976, have reported the hepatic and renal toxicity of rifampicin. More so, ATTIA, 2007, DHULEY \& NAIK, 1998, and SADRIEH \& SNYDERWINE, 1995 have reported the mutagenic potential of rifampicin. The study of
MINDERMANN et al., 1998 also reported the potential of rifampicin to cross the blood brain barrier and have a high concentration in the Staphylococcal and Streptococcal brain infections. It has also been found to increase lipid peroxidation activity in the liver and bone marrow (DHULEY \& NAIK,1998). However, antioxidants have been known to scavenge free radicals which are often produced by the activities of some drugs; free radicals are known to cause damage to cells, tissues and human organs. Thus, scavenging free radicals may prevent adverse destruction of the architecture and functions of the body components.

Therefore, this present study intends to use an in vivo method to determine the toxicity of rifampicin and the modulatory activity of the antioxidants (vitamin $\mathrm{C}$ or $\mathrm{E}$ ) against rifampicin induced hepatotoxicity, sperm quality and meningeal congestion.

\section{METHODOLOGY}

Forty rats (10 per group) were randomly allotted to four groups, consisting of the control, the rifampicin treated group, the rifampicin plus vitamin $\mathrm{E}$ treated group and the rifampicin plus vitamin $\mathrm{C}$ treated group. 
AWODELE, O.; AKINTONWA, A.; OSUNKALU, V.O. \& COKER, H.A.B. - Modulatory activity of antioxidants against the toxicity of rifampicin in vivo. Rev. Inst. Med. Trop. São Paulo, 52(1): 43-46, 2010.

Therapeutic doses of rifampicin $(9 \mathrm{mg} / \mathrm{kg} /$ day $)$, vitamin $\mathrm{E}(5 \mathrm{mg} / \mathrm{kg})$ and vitamin $\mathrm{C}(8 \mathrm{mg} / \mathrm{kg})$ were administered to the animals. The doses were administered via oral gavage, daily over 90 days. Rats in different groups were observed closely, looking for any behavioral change, feeding and drinking habits, as well as body weight and general morphological changes. After 90 days, rats were sacrificed for internal macroscopic and histological examination of the organs, sperm analysis and biochemical investigations. Liver enzymes and total bilirubin, known to be important markers in liver damage (ALT and AST) and lipid profile were estimated using fully an automated clinical chemistry analyzer (Hitachi 912, Boehringer Mannheim, Germany). The sperm count, motility and morphological aberrations were determined using the methods of MORAKINYO et al., 2008.

Results are presented as mean \pm S.E.M. Statistical significance between the control groups and the test groups were analyzed by means of student t-test. $P$ values less than 0.05 were considered significant.

\section{RESULTS}

Table 1 shows rifampicin alone to significantly $(\mathrm{p}<0.05)$ increase the level of AST, ALT and total bilirubin when compared with the control. Rifampicin alone also resulted in a low, non-significant $(p>0.05)$ increase in the level of HDL, LDL and cholesterol when compared with the control. The co-administration of rifampicin and Vitamin E showed a significant ( $\mathrm{p}$ $<0.05)$ decrease in the levels of AST $(400.83 \pm 10.48$ in rifampicin alone and $310.2 \pm 6.75$ rifampicin plus Vitamin E) and small, non-significant decrease in the level of ALT $(143.96 \pm 2.59$ in rifampicin alone and 142.0 \pm 2.04 in rifampicin plus vitamin E). A significantly $(\mathrm{p}<0.05)$ decreased level of bilirubin was observed in rifampicin plus vitamin $E$ treated group when compared to rifampicin alone. The results showed rifampicin plus vitamin E treated group to significantly $(\mathrm{p}<0.05)$ increase the level of HDL when compared with rifampicin alone and the control group. There was also non-significant increase in the level of LDL and cholesterol in the rifampicin plus Vitamin E treated group when compared with the control and rifampicin alone treated groups. Results obtained with the rifampicin plus vitamin $C$ treated group showed a significant decreased $(p<0.05)$ in the level of bilirubin when compared with the rifampicin alone treated group. The results also showed a small, non-significant $(p>0.05)$ decrease in the level of ALT $(141.33 \pm 4.36)$ when compared with the rifampicin alone. There was no difference in the values of $\operatorname{HDL}(0.8 \pm 0.0)$ and LDL $(0.3 \pm 0.1)$ from rifampicin alone treated group.

Figures $1 \mathrm{~A}$ and $\mathrm{B}$ showed the effect of rifampicin alone, rifampicin plus vitamin $\mathrm{E}$ and rifampicin plus vitamin $\mathrm{C}$ in the motility and abnormal morphology of rats' sperm. The results showed rifampicin to significantly ( $\mathrm{p}$ $<0.05$ ) decrease the sperm motility when compared to control group. The vitamin $\mathrm{E}$ and $\mathrm{C}$ treated group showed a significant $(\mathrm{p}<0.05)$ improvement in the sperm motility when compared with the single rifampicin treated group.

Moreover, the morphology results demonstrated that rifampicin adversely affects the sperm quality leading to a significant $(\mathrm{p}<0.05)$ increase in the abnormality percentage of the samples when compared with the control group. However, the vitamin $\mathrm{E}$ or $\mathrm{C}$ treated group showed a significant $(\mathrm{p}<0.05)$ decrease in the percentage abnormality when compared with the rifampicin treated group.

Figure 2 shows that rifampicin significantly $(\mathrm{p}<0.05)$ decreases the sperm count when compared with the control group. However, the coadministration of vitamin $\mathrm{E}$ or $\mathrm{C}$ showed a significant $(\mathrm{p}<0.05)$ increase in the sperm count when compared to the rifampicin alone treated group.

Figure 3 shows micrograph $3 \mathrm{~A}, \mathrm{C}, \& \mathrm{D}$, normal brain without

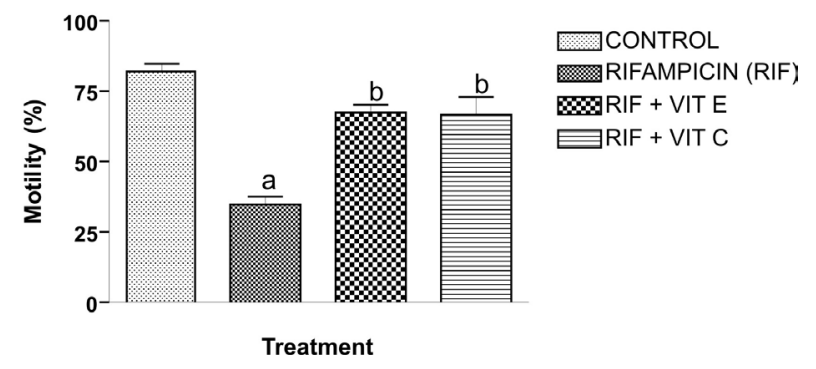

Fig. 1A - Modulatory activity of vitamin $\mathrm{E}$ or $\mathrm{C}$ on the caudal epididymis sperm motility in rifampicin treated rats. a: $\mathrm{p} \leq 0.05$ compare with control; $\mathrm{b}$ : $\mathrm{p} \leq 0.05$ compare with rifampicin.

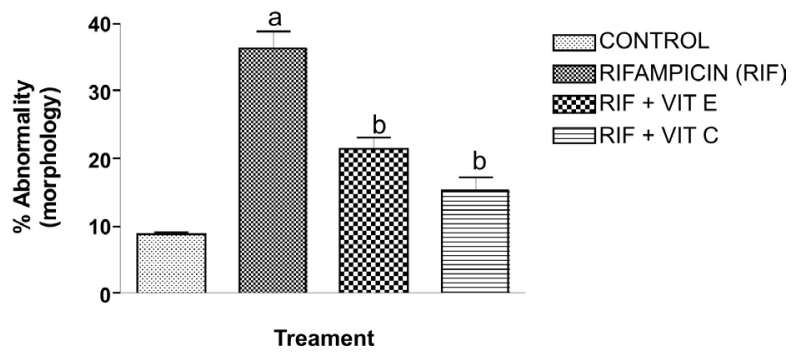

Fig. 1B - Modulatory activity of vitamin E or C on the caudal epididymis sperm morphology in rifampicin treated rats. $\mathrm{a}: \mathrm{p} \leq 0.05$ compare with control; $\mathrm{b}$ : $\mathrm{p} \leq 0.05$ compare with rifampicin.

Table 1

Blood chemistry parameters of rats after 90-day sub chronic treatment with rifampicin and rifampicin plus vitamin $\mathrm{E}$ or C

\begin{tabular}{|c|c|c|c|c|c|c|}
\hline \multirow[t]{2}{*}{$\begin{array}{l}\text { Treatment } \\
\text { Group }(n=10)\end{array}$} & $\begin{array}{l}\text { AST } \\
(\mathrm{U} / \mathrm{L})\end{array}$ & $\begin{array}{c}\text { Total } \\
\text { Bilirubin }\end{array}$ & $\begin{array}{l}\text { ALT } \\
(\mathrm{U} / \mathrm{L})\end{array}$ & \multirow[t]{2}{*}{$\begin{array}{c}\text { HDL } \\
\mathrm{mg} / 100 \mathrm{~mL}\end{array}$} & \multirow[t]{2}{*}{$\begin{array}{c}\text { LDL } \\
\mathrm{mg} / 100 \mathrm{~mL}\end{array}$} & \multirow[t]{2}{*}{$\begin{array}{c}\text { CHOL } \\
\mathrm{mg} / 100 \mathrm{~mL}\end{array}$} \\
\hline & & $(\mathrm{Mg} / \mathrm{L})$ & & & & \\
\hline Control & $229.0 \pm 3.0$ & $2.96 \pm 0.06$ & $66.0 \pm 1.0$ & $0.7 \pm 0.07$ & $0.2 \pm 0.02$ & $1.37 \pm 0.02$ \\
\hline Rifampicin alone & $400.83 \pm 10.48^{\mathrm{a}}$ & $6.26 \pm 1.11^{\mathrm{a}}$ & $143.96 \pm 2.59^{\mathrm{a}}$ & $0.8 \pm 0.1$ & $0.3 \pm 0.1$ & $1.47 \pm 0.32$ \\
\hline Rifampicin plus Vit. E & $310.2 \pm 6.75^{\mathrm{ab}}$ & $3.14 \pm 0.27^{\mathrm{b}}$ & $142.0 \pm 2.04^{\mathrm{a}}$ & $1.06 \pm 0.05^{\mathrm{ab}}$ & $0.4 \pm 0.2$ & $1.54 \pm 0.11^{\mathrm{a}}$ \\
\hline Rifampicin plus Vit. C & $400.90 \pm 54.88^{a}$ & $4.09 \pm 0.89^{b}$ & $141.33 \pm 4.36^{\mathrm{a}}$ & $0.8 \pm 0$ & $0.3 \pm 0.1$ & $1.21 \pm 0.05^{\mathrm{a}}$ \\
\hline
\end{tabular}

Serum alanine amino transferase (ALT), Aspartate amino transferase (AST), High density lipoprotein (HDL), Low density lipoprotein (LDH), Cholesterol (CHOL). $\mathrm{a}$ : $\mathrm{p}<0.05$ in comparison with the control group; $\mathrm{b}$ : $\mathrm{p}<0.05$ in comparison with rifampicin group; $\mathrm{n}$ : number of animals per group. 


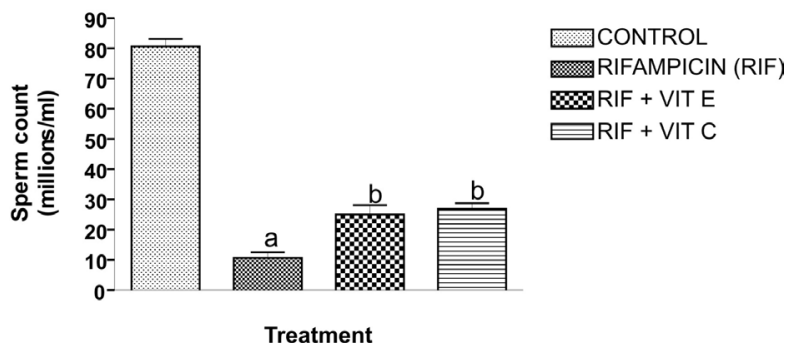

Fig. 2 - Modulatory activity of vitamin $\mathrm{E}$ or $\mathrm{C}$ on the caudal epididymis sperm count in rifampicin treated rats. a: $\mathrm{p} \leq 0.05$ compare with control; $\mathrm{b}$ : $\mathrm{p} \leq 0.05$ compare with rifampicin.
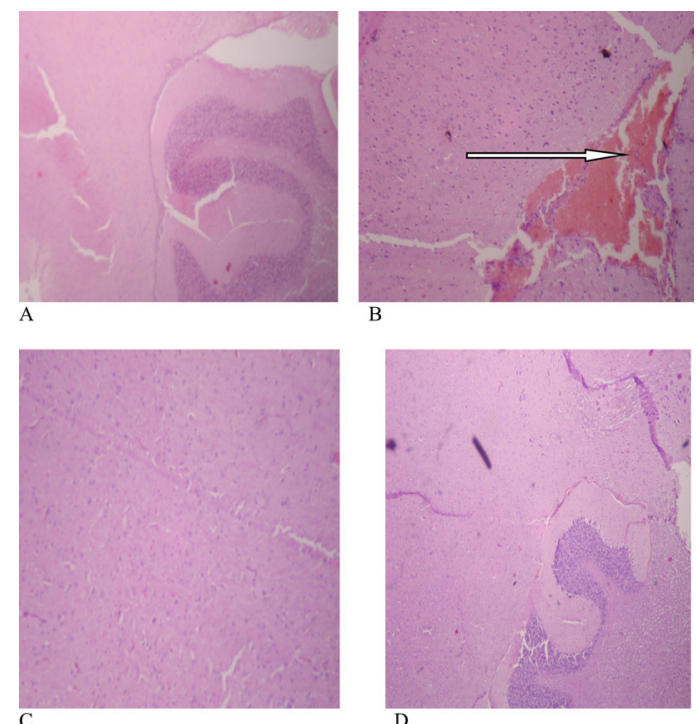

Fig. 3 - The micrographs of the brain sections obtained from untreated and treated rats with rifampicin and rifampicin plus vitamin C or E. Magnification x 40. A: control (untreated rat); B: rat treated with rifampicin alone; $\mathrm{C}$ : rat treated with rifampicin plus vitamin $\mathrm{E} ; \mathrm{D}$ : rat treated with rifampicin plus vitamin $\mathrm{C}$.

meningeal congestion. Micrograph 3B shows congestion of the meninges.

Figure 4 shows in micrographs 4A, C \& D normal epididymis images, with the epididymis lumen filled with sperm cells. Micrograph 4B shows the epididymis with a reduced number of sperm cells into the lumen.

\section{DISCUSSION}

The results showed rifampicin alone to significantly $(\mathrm{p}<0.05)$ increase the level of AST, ALT and total bilirubin, which corroborates the data of the study of REKHA et al., 2005. The results of the histopathological examination (data not shown) also showed remarkable damage to the architecture of the liver cells. This is an indication that rifampicin is toxic to the liver and it is in agreement with the earlier reports of SARASWAT et al., 1997 that showed that rifampicin induces hepatic damage and increase total bilirubin by reducing the bile flow as well as its content. A significant $(\mathrm{p}<0.05)$ decrease in sperm count, motility and increased in sperm morphological abnormality were found in the rifampicin treated group when compared with the control group. This may be correlated with the previous reports of NOCKE-FIUCK \& BREYER, 1981 and CASTELLANOS \& HERNANDEZ, 1975 that

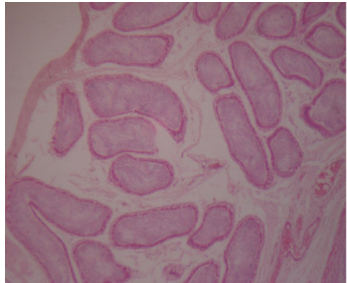

A

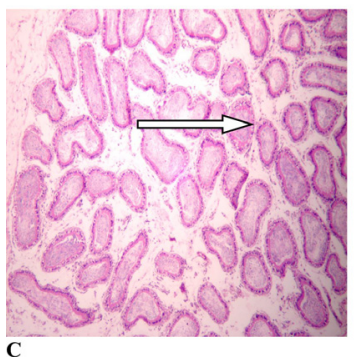

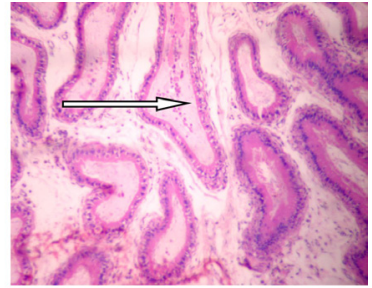

B

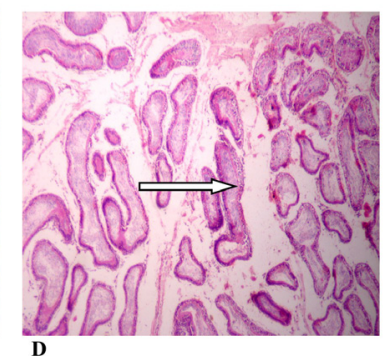

Fig. 4 - The micrographs of the epididymis sections obtained from rats untreated and rats treated with rifampicin and rifampicin plus vitamin $\mathrm{C}$ or E. Magnification x 40. A: control (untreated rat); B: rat treated with rifampicin alone; C: rat treated with rifampicin plus vitamin E; D: rat treated with rifampicin plus vitamin C.

showed rifampicin to act on the 17 alpha hydroxylaxin in the microsomal fraction of rat testes. Rifampicin also produced a small, non-significant rise in the levels of HDL, LDL and cholesterol when compared with the control. This may be consistent with the work of DHULEY AND NAIK, 1998 that showed rifampicin to cause an increase in lipid peroxidation.

The co-administration of rifampicin and vitamin E showed a significant $(\mathrm{p}<0.05)$ decrease in the levels of AST and a small, nonsignificant decrease in ALT levels. Moreover, a significant $(\mathrm{p}<0.05)$ decrease in the level of bilirubin was observed in the rifampicin plus vitamin E treated group. These effects may be linked to the ability of the antioxidant to scavenge free radicals (OAKELY, 1998).

The results further showed rifampicin plus the vitamin $\mathrm{E}$ treated group, to significantly $(\mathrm{p}<0.05)$ increase the level of HDL when compared with the rifampicin alone group. There was also a small, nonsignificant increase in the level of LDL and cholesterol in the rifampicin plus vitamin E treated group. This may be due to pro-oxidant effect of some antioxidants (DUARTE \& LUNEC, 2005).

The results obtained with the rifampicin plus vitamin $\mathrm{C}$ treated group showed a significant decrease $(p<0.05)$ in the level of bilirubin when compared with the rifampicin treated group alone. It also showed a small, non-significant decrease in the level of ALT (141.33 \pm 4.36$)$ when compared with the rifampicin alone group. There was no difference in the values of HDL $(0.8 \pm 0.0)$ and LDL $(0.3 \pm 0.1)$ from the Rifampicin alone group. The lack of effect of vitamin $\mathrm{C}$ on the lipid profile when compared with rifampicin alone may be due to its more antioxidant properties than prooxidant effect (VALKON et al., 2005).

This study also showed that vitamin $\mathrm{E}$ or $\mathrm{C}$ treated groups significantly $(p<0.05)$ improved the sperm count and motility, and also reduced the morphological abnormality of sperm cells. The histopathological findings corroborated the protection of vitamin $\mathrm{C}$ or $\mathrm{E}$ against the damage caused 
by rifampicin to the epididymis. Thus, the previous studies of WANG et al., 2007 and ROMAN, 2006 have shown that antioxidants preserve the semen quality and are beneficial in sperm function and qualities. Rifampicin is able to penetrate the blood brain barrier and caused congestion of the meninges as shown in the histopathological findings presented in this study. However, the co-administration of rifampicin and vitamin $\mathrm{C}$ or $\mathrm{E}$ showed protection of the brain against the damage caused by rifampicin alone. This protective effect may be due to the antioxidant properties of vitamins $\mathrm{C}$ and $\mathrm{E}$, which can scavenge the free radicals that could cause brain cells damage.

\section{CONCLUSION}

This study has shown that vitamin $\mathrm{E}$ and $\mathrm{C}$ improved sperm quality and protected the meninges against rifampicin toxicity. Vitamin $\mathrm{E}$ also demonstrated remarkable protection against rifampicin induced hepatic damage. However, vitamin $\mathrm{C}$ hepatoprotective effect against rifampicinmediated hepatic damage is questionable.

\section{LIMITATION}

This present study did not measure the lipid peroxidation, neither in liver nor in serum. Thus, further study in this area should incorporate the determination of lipid peroxidation in the liver, serum and spermatozoa, so as to establish the level of oxidative damage.

\section{RESUMO}

\section{Atividade modulatória de anti-oxidantes contra a toxicidade da rifampicina in vivo}

A Organização Mundial da Saúde tem mostrado preocupação acerca da eclosão da tuberculose nos países em desenvolvimento. Embora a rifampicina seja droga efetiva para o controle da tuberculose têm sido documentados seus efeitos tóxicos em pacientes. Portanto este estudo tem a intenção de investigar o efeito modulador das vitaminas $\mathrm{C}$ e $\mathrm{E}$ na hepatotoxicidade, qualidade de esperma e a toxicidade cerebral da rifampicina.

Quarenta ratos albinos da raça Wistar foram usados, 10 animais por grupo. $\mathrm{O}$ grupo 1 de animais recebeu $0,3 \mathrm{~mL}$ de água destilada. $\mathrm{O}$ grupo 2 recebeu a dose terapêutica de rifampicina. $\mathrm{O}$ grupo 3 recebeu doses terapêuticas de rifampicina mais vitamina $\mathrm{E}$, enquanto o grupo 4 recebeu doses terapêuticas de rifampicina e vitamina C. A administração foi feita por via oral durante três meses; os animais foram sacrificados por deslocação cervical após este período. Amostras sanguíneas foram coletadas e função hepática e o perfil lipídico foram analisados usando aparelho automático de química clínica. O fígado, o cérebro e os órgãos reprodutivos foram submetidos a análise histopatológica. As amostras de esperma foram coletadas do epidídimo para contagem, motilidade e análise morfológica.

Resultados revelaram que a rifampicina isoladamente aumenta $(\mathrm{p}<0,05)$ os enzimas de função hepática (aspartato amino transferase \{AST], alanino amino transferase sérica [ALT] e bilirrubina total) quando comparados com os controles. Embora o grupo tratado com vitamina E mostrasse marcada proteção, o grupo tratado com vitamina $\mathrm{C}$ mostrou proteção questionável contra a lesão hepática induzida pela rifampicina. Resultados da contagem espermática mostraram importante $(\mathrm{p}<0,05)$ aumento na qualidade do esperma no grupo tratado com vitamina E e C. Entretanto, o grupo tratado com vitamina E e rifampicina mostrou aumento da peroxidação lipídica. Os achados histopatológicos revelaram danos estruturais pela rifampicina ao fígado, cérebro e epidídimo enquanto uma notável integridade arquitetural foi observada no grupo tratado por anti-oxidantes.

Pode-se concluir que as vitaminas E e C melhoraram a qualidade do esperma e protegeram o cérebro de danos causados pela rifampicina. Mais ainda, a vitamina $\mathrm{E}$ demonstrou notável hépato-proteção contra o dano induzido pela rifampicina enquanto a vitamina $\mathrm{C}$ mostrou hépatoproteção questionável.

\section{REFERENCES}

1. Attia SM. Chromosomal composition of micronuclei in mouse bone marrow treated with rifampicin and nicotine, analysed by multicolor fluorescence in situ hybridization with pancentromeric DNA probe. Toxicology. 2007;235:112-8.

2. Castellanos JM, Hernandez A. Influence of Rifampicin on testosterone metabolism in the rat prostate. Hormone Metabol Res. 1975;7: 270-1.

3. Dhuley JN, Naik SR. Modulation of rifampicin toxicity by 6 MFA an interferon inducer obtained from fungus Aspergillus ochraceus. Environm Toxicol Pharmacol. 1998;5:237-43.

4. Duarte TL, Lunec J. When is an antioxidant not an antioxidant? A review of novel actions and reactions of vitamin C. Free Radic Res. 2005;39:671-86.

5. Gabow PA, Lacher JW, Neff TA. Tubulointerstitial and glomerular nephritis associated with rifampicin. J Am Med Assoc. 1976;23:2517-8.

6. Katz MD, Lor E. Acute interstitial nephritis associated with intermittent rifampicin use. Drug intellig Clin Pharmacy. 1986;20:789-92.

7. Mindermann T, Zimmerli W, Gratzl O. Rifampicin concentration in various compartments of the human brain: a novel method for determining drug levels in the cerebral extracellular space. Antimicrob Agents Chemother.1998;42:2626-9.

8. Morakinyo AO, Oloyo AK, Raji Y, Adegoke OA. Effects of aqueous extract of garlic (Allium sativum) on testicular functions in the rat. Nigerian J Health Biomed Sci. 2008;7(2):26-30.

9. Nocke-Fiuck L, Breyer H. Effect of rifampicin on the biosynthesis of testosterone in rat testes. Acta Endocrinol (Copenh). 1981;97:573-6.

10. Oakely RT. Free radicals. Prog Inorg Chem. 1998;36:299.

11. Rekha VV, Santha T, Jawahar MS. Rifampicin induced renal toxicity during retreatment of patients with pulmonary tuberculosis. J Assoc Physician India. 2005;53:811-3.

12. Roman B. Vitamin C supplements help reverse male infertility. Health sentinel. 2006.

13. Sadrieh N, Snyderwine EG. Cytochrome P450 in Cynomolgus monkeys mutagenically activate 2-amino-3-methylimidazo(4, 5-f) quinoline (IQ) but not 2-amino-3, 8-dimethylimidazo(4, 5-f) quinoxaline (MeIQx). Carcinogenesis. 1995;16:1549-55.

14. Saraswat B, Visen PK, Patnaik GK, Dhawan BN. Hepatoprotective effect of picroliv against rifampicin induced toxicity. Drug Develop Res. 1997;40:299-303.

15. Valkon M, Morris H, Cronin MT. Metals toxicity and oxidative stress. Curr Med Chem. 2005;12:1161-208.

16. Wang S, Wang G, Barton BE, Murphy TF, Huang HFS. Beneficial effects of vitamin $\mathrm{E}$ in sperm functions in the rat after spinal cord injury. J Androl. 2007;28:334-41.

17. World Health Organization. Treatment of tuberculosis: guidelines for national programmes. $2^{\text {nd }}$ ed. Geneva: WHO; 1997.

Received: 10 March 2009

Accepted: 17 November 2009 